\title{
Constructing an Alternative Concept of Islamic Governance: A Maqāṣidic Approach
}

\author{
MASZLEE MALIK \\ Office of the Education Minister of Malaysia, Level 18, No. 2, Tower 2, Jalan P5/6, \\ Presint 5, 62200 Putrajaya, Malaysia \\ maszlee@moe.gov.my
}

Published online: 15 August 2019

To cite this article: Malik, M. 2019. Constructing an alternative concept of Islamic governance: A maqāșidic approach. KEMANUSIAAN the Asian Journal of Humanities 26(Supp. 1): 89-108. https://doi.org/10.21315/kajh2019.26.s1.5

To link to this article: https://doi.org/10.21315/kajh2019.26.s1.5

\begin{abstract}
The common perception of Islamic governance is a dark image of a nondemocratic and autocratic system, or a dictatorship with iron claws, or the governance of the cleric elite with the infringement of people's freedom under the banner of religion. This is mainly due to the fiqhi "legal positivistic" framework that is often used to explain issues concerning governance by mostly traditionalist and Islamicist scholars. Humanistic governance based on the preservation of the dignity of human beings, which has been the focal point in Islamic tenets, the inviolability of life, and responsible freedom should be explored and promoted as another alternative voice of the dominating conventional fiqh $\bar{\imath}$ legal positivistic hegemony. Thus, a new ijtihäd (reasoning) in dealing with the subject is absolutely mandatory. This paper will look into a new approach to governance from the "consequentialistic" approach inspired by the general theory of Maqassid al-Sharī ah. This research will explore some conceptual grounds for the exploration by looking into the epistemological dimension of governance from Islamic sources and principles through "inductive qualitative method" to critically analyse the texts, as part of the deconstruction of discourse.
\end{abstract}

Keywords and phrases: governance, ijtihād, Maqāssid al-Sharī'ah, modernity, tawhīd

* Maszlee Malik (Dr.) is currently the Education Minister of Malaysia and was previously an Assistant Professor at the Department of Political Science, Kulliyyah of Revealed Knowledge and Human Sciences, International Islamic University Malaysia (IIUM), Kuala Lumpur, Malaysia.

(C) Penerbit Universiti Sains Malaysia, 2019. This work is licensed under the terms of the Creative Commons Attribution (CC BY) (http://creativecommons.org/licenses/by/4.0/). 


\section{Introduction}

It is an incontrovertible fact that religions and belief systems have their own unique proactive role in the evolution of both ancient and modern civil societies. It impacts the development of a country, playing an important role in its economic, political and social governance (Ghaus-Pasha 2005). Essentially, religion as a form of ethical doctrine could potentially provide the "internal good" for development through its doctrines on social cohesion, mutual cooperation and virtue-based community. Cortina surmised that traditional bond can motivate the work of development by motivating the society to attain the internal goods within certain ethical and moral frameworks through the cultivation of virtues by different social agents according to certain models facilitated by political, economic, and citizens' institutions based on specific philosophical foundations (2007, 5-6). Her framework emphasises the importance of the ethical man within the system and not merely as a means towards a political or economic end-point.

Religion, as viewed from this new perspective, is no longer mere beliefs in miraculous rescue from the heavens (deus ex machina) but rather a vehicle for human betterment (Falk 2001, 32). Many empirical studies of this relationship seem to suggest that religions, through faith-based or faith-inspired organisations and movements, have not contributed significantly to human development. The research studied the impact of these instruments of religion in the eradication of poverty, provision of educational opportunities, welfare services to the community, enhancement of humanitarian works, and its involvement in the political process to fight against corruption and misadministration (see Akhtar 1995; Casanova 1994; Gillingham 2005; Gutiérrez 1988; Harrigan and El-Said 2009; Marshall 2005; Phongphit 1988; Rowland 1999).

In an attempt to further explore the framework suggested by Cortina, this paper will study the issue of Islamic governance vis a vis human and societal development from an epistemological point of view as inspired by the general theory of Maqāsid al-Sharī 'ah (higher objectives of the sharī 'ah). The research utilises an "inductive qualitative methodology" (istiqra') to explore some conceptual frameworks and critically analyse the texts from authentic Islamic sources.

\section{Islam and Governance: A New Horizon}

The common perception of Islamic governance is one of a dark image of a nondemocratic and autocratic system, an iron clad dictatorship, or a despotic rule by the cleric elite under the banner of religion. All of these, which unfortunately resemble the reality in some contemporary Muslim countries, are known and 
accepted as major impediments to development. Unfortunately, these political realities in Muslim countries further reinforce the stereotyping by Western sceptics of the ugly presence of religion in the political sphere.

Umer Chapra (2008b, 846) challenged the prejudices of these cynics by invoking Ibn Khaldun's theory of the rise and fall of civilisations. Ibn Khaldun wrote that Islam activates all the indispensable factors in a positive discretion through a multidisciplinary approach to development. The approach encompasses allimportant socio-economic and political variables, including sovereign or political authority, beliefs and rules of behaviour ( shari $^{\prime} a h$ ), people, wealth or stock of resources, development, and justice, in a circular and interdependent manner.

Ibn Khaldūn (2005 [1967], 19) concluded that the rise and fall of civilisations is closely dependent on the well-being or misery of the people. Therefore, the fall of any civilisation is not solely dependent on economic variables but is also due to the combined permutations of moral, institutional, psychological, political, social and demographic factors (Chapra 2008b, 840). As a remedy, Ibn Khaldun proposed the activation of the Islamic creed, spirituality and horizontal-vertical moral values to contribute to the moral and material uplifting of individuals, which is the central factor behind the rise or fall of civilisations and countries.

Nonetheless, totally rejecting the sceptics as argued by apologists would not enhance the discourse or totally accepting them at face value. This research suggests that Islamic texts have been manipulated, are being manipulated or could be manipulated by persons or parties to legitimise their undemocratic governance. Hence, there is an urgent and dire need for laying the dimensions of governance from Islamic epistemology, by carefully considering the interplay of the values of justice, fairness and the human experience. Thus, a new ijtiha $\bar{d}$ (reasoning) is needed to review, analyse and rationalise this subject.

The preservation of human dignity, the inviolability of life, and people's freedom should always be embraced, protected and promoted within any "Islamic"-inspired governance. Malek Bennabi stressed that a comprehensive understanding of the essence of Islam will lead towards the appreciation of values that honour the dignity of the children of Adam (al-Karamah al-Insāniyyah) as mentioned in verse 70 , chapter 17 of al-Qur'an. The verse assimilates a divine element within man as the foundation of the decorum of dealings between mankind, thus, every human being must be empowered and their rights to be respected.

Therefore, a new approach is required to crystallise the Islamic principles of governance based on the value-laden, ontology-determined epistemology of 
Islam. Undoubtedly, this new approach must transcend the present (nature-matter) materialistic monism of governance with new presuppositions derived from Islamic epistemology (see Choudhury 1992, 1993, 1994, 1999), replacing the ends of its process with transcendental values, and by making humans as a starting point of the subject and not as mere commodities which apply modern socioeconomic analysis. Furthermore, it must fit into the framework of comprehensive contemporary usage of "good governance".

\section{Islamic Worldview of Governance: A Methodological Transformation}

The epistemological question revolves around what is commonly referred to as a person's Weltanschauung or worldview. Weltanschauung is understood as "a comprehensive view or philosophical conception of life, world and universe especially from a specific standpoint" (Collins English Dictionary 1998, 1731; Fowler and Fowler 1995, 1592), which is also best described as "a set of implicit and explicit assumptions about the origin of the universe and the nature of human life" (Chapra 1992, 1). Similar to a building with its solid foundation, man's worldview serves as a crucial base for him since the way he thinks, behaves and acts are directly influenced by his worldview. Different worldviews lead to different sets of values and norms (Chapra 1992, 1-10), which, as rationalised later, justify Islamic governance through the Islamic worldview.

The epistemological aspects are especially crucial to determine the foundation required for an axiomatic approach towards developing the concept of an "Islamic governance". Philosophical enquiries are therefore essential to determine the parameters of the new theory and knowledge; which makes it unique from other belief systems and differentiates it from earlier interpretations by fellow believers.

The Islamic worldview, based on the principal of tawhid or the oneness of Allah as the All Mighty Creator, implies that human beings were created as the vicegerent (khalifah) of God, to shoulder the trust as His representative on earth, to submit themselves to the servitude of the All Mighty and to prosper the earth for human's well-being. This worldview is the essence of the ontological conviction of every conscious Muslim.

Upon such rationale, the quest to formulate an Islamic model of governance requires new ijtihād to converge both aspects of revealed and acquired knowledge. New methods, which are more dynamic but at the same time normative, should be employed to proliferate new ideas on Islamic governance; yet conforming to the parameters of a tawhīdic determined epistemology. 
Accordingly, this new method demands a significant examination of ontologically determined epistemological sources to ensure the originality of the new model in terms of sources, framework, concepts and objectives. Revelation, represented by the Qur'an ${ }^{1}$ and Sunnah (Prophet Muhammad's authentic traditions) are major references in the realm of Islamic epistemology, ${ }^{2}$ while the history of the four guided Caliphs (al-Khulafä' al-Räshidūn), as a historical proof on the articulation of the revelation, is another undisputed source in such formulation. However, this does not confer any divinity to their experience or any impeccability to their actions. Finally, Maqūșid al-Sharī ah (higher objectives of sharì ah) represents another epistemological source towards understanding revelation and fathoming any "implicit general idea" or hidden wisdom of sharī'ah in its wider framework to be reflected unto the field of governance.

This method harmonises revelation and 'aql (rationality), or even more, it confers rationality an expanded role in interpreting the revealed texts (Al-Qaraḍāwī 2004, 70). Despite its heavy dependence on reason, the maqassidic approach faithfully honours the tawhidic reality as the bedrock for its ontology. However, the postmodern world demands the contemporary Muslim scholar to deal with the texts beyond the traditional and classical way of the earlier fuqaha' (jurists). The revealed texts must be put to the test of an epistemological enquiry to understand its meaning and relevance to the evolving human existence. The new reality of human knowledge and the expansion of the Qur'an-Sunnah episteme requires a re-reading of both revealed scriptures (see Al-Alwani 1991). This new approach, however, does not involve the modification of the sources, but rather a transformation of the mind and eyes that read them, which are naturally influenced by the new social, political, economic, geographical and scientific ambience (Ramadan 2006, 4).

This proposed method in approaching the texts is akin to the call for renewal and the re-reading of texts that was proposed by 19 th-century reformists, namely the late al-Afghani and his disciple, Muhammad "Abduh who strongly advocated the call for reform (islah wa tajdid). "Abduh (1966) in his "eclectic theology approach" proposed that the shari 'ah is equivalent to natural law with the exception of religious rites (ta'abbudi) (Enayat 1982). In expanding the guidance of al-Qur'an and shunning away from the limitation of the traditional literal exegesis of al-Qur'an, 'Abduh wrote: "On the Last Day God will not question us, the commentators on how they understood the Qur'an, but He will question us on His Book which $\mathrm{He}$ sent down to guide and instruct us" (Jansen 1974, 19). 


\section{Good Governance and Maqāṣid al-Sharī ah}

Towards harmonising the rational and revelation, Muslim scholars have engaged with both the Qur'an's and the Sunnah's implicit messages through varying methods. The methods were applied to understand the implicit messages of the revealed texts and derive the universal messages which were being communicated to human beings. Ibrāhim al-Nakhā' $\overline{1}$ (d. $96 \mathrm{H})$ described it as: "Verily, the rulings of Allah have their own specific objectives which are reflected as benefit and wisdom upon mankind" (Al- 'Ubaydī 1992, 132). With the same understanding, another classical jurist, Al- 'Izz ibn 'Abd al-Salām (n.d., 1:9) claimed that "the greatest of all the objectives of the Qur'an is to facilitate benefits (mașālih) and the means that secure them and that the realisation of benefit also included the prevention of harm".

It could be comprehended from his word that all the obligations of the shari' $a h$ were predicated on securing benefits for the people in this world and the next, and it is the duty of Muslims to discover them, observe them in their daily life and implement them in their daily duties (Al-'Ubaydī, 1992, 132). These objectives were later expounded by al-Ghazāli $(1993,286-287)$ who maintained that the objective of shari ${ }^{\prime} a h$ is to preserve or protect the mașälih (singular: maslahah), exemplified by five main essentials of human beings: faith (din), life (nafs), intellectual ( 'aql), property $(m \bar{a} l)$ and lineage (nasl). ${ }^{3}$ Al-Ghazâlī deduced that the major purpose of shari 'ah law is to "safeguard" or preserve those essentials, which eventually bring benefit for human life. Following a similar rationale, alTufī concluded that the preservation of these objectives consists in both "attracting utility" ( jadhb al-naf') and "repelling harm" (raf al- darar), and should be used as the major source of law after the Qur'an and the Sunnah (Al-Ṭūfin 1989, 239).

He adds further, that in some cases of mu'amalat (contracts and transactions), maqāssid would supersede some minor rulings in the Qur'an and the Sunnah to achieve the highest objectives. However, in the issues of 'ibadat (rituals or spiritual duties) which involves direct interactions with God, and considered as God's rights, the human mind cannot and should not attempt to discern the reasons behind the textual injunctions unlike the mu'amalat, where God delegated to humanity the right and duty to set up just rules and regulations in accordance with the public interest (mașlahah). It should be noted that prior to al-Shātibī's definition of al-maqāṣid, other writers namely al-Juwayni, ${ }^{4}$ al-Ghazālī and al- 'Izz ibn 'Abd al-Salām emphasised more on the notion of "protection" and "preservation". The word "hifz" (protection) has been recognised as the ultimate objective of shari' 'ah. 
To fully understand the Maqāșid al-Sharī ah approach, one must closely analyse al-Shatibi's comprehensive description of the maqūșid. According to al-Shātịīi, sharí $a h$ is not only being revealed to protect or preserve the mașlahah, but it also promotes the maslahah in order to realise its benefits for human life. The five essentials in human life (or six according to some) are not only being protected and preserved, but also being promoted and propagated as could be understood from a deductive reasoning of the revelation. Such extensive and all-encompassing concepts of mașlahah, infuses substance and vigour into the external shell of Islamic rulings and law, thus showing that moral obligation is closely related to Divine Omnipotence and Will and that the former necessarily flows from the latter (Rahman 1979, 115). With the proper understanding of such philosophy, the application of a true understanding of revelation could avoid the legal positivistic approach, which acts according to the formulated law without responding to the moral consequences of it.

Drawing on the Qur'anic verses: "We sent you not but as a mercy for all creatures" (107:21); "Allah does not wish to place you in difficulty, but to purify you, and to complete His favour to you" (6:5); and "In the Law of Equality there is (saving of) life to you" (179:2), al-Shātịīi (1996, 2:326) wrote:

Upon exploration of sharì $a h$ we have concluded that it was only set up to serve the interests of man. This is a conclusion that no one can dispute. Canon laws were made for only one purpose and that is to serve the interests of humans in this life and in the Hereafter.

However, Ibn al-Qayyim (1973, 4:309-311) viewed the maqāsid from a different perspective, emphasising that justice and equity in ensuring welfare, as the utmost mașlahah to be preserved through Islamic sharì ah. Furthermore, he insisted that the means to justice and equity could never be captured by a finite list; hence, reason will guide the Muslims on how to ensure both justice and equity in changing circumstances. The articulation of maquassid from this expanded point of view would be helpful towards developing policies based on Islamic ontology. Similarly, al-Qaraḍāwī (1993) opined a more inclusive approach to maqāșid and further extended the list of the maqāsid according to the contemporary reality and discourse to include social welfare and support (al-takaful), freedom, human dignity and human fraternity, among the higher objectives of the shari'ah. Ibn 'Āshūr (2006) added three more qualities: freedom (al-Hurriyah), justice (al- 'Adālah) and equality (al-Musāwah). These are undoubtedly upheld by both the detailed and the general weight of evidence in the Qur'an and the Sunnah. 
To conclude the discussion about the importance of maqāsid, we could summarise that the maqāssidic method represents a comprehensive, holistic and universal approach towards sharì $a h$. Any study conducted on Islam, the shari' $a h$ or the epistemological sources of Islam is incomplete without a discussion on maqāssid. The maqāșidic approach represents a crucial tool in understanding the explicit and implicit intent of the revealed texts; whereby a misinterpretation may lead to dire consequences to the authentic expressions of Islam as a whole.

\section{Towards A Maqāạsidic Governance}

In presenting a new normative governance theory based on Maqūșid al-Sharī'ah, the struggle to achieve the maq assid should be the focal point in operationalising and articulating the principles for governance as a practical reality. The accomplishment of maqassid in the governance process can be a benchmark of an accomplishment of "good" in the governance process. This situation can be explained in the modern jargon of "human well-being" (see Malik 2015). As such, good governance from an Islamic point of view is a governance process which consists of the maqāsidic elements to fulfil the maqāșidic end.

This paradigm imposes multi-dimensions of benefits, which encompass both individuals and community benefits, in this world and the Hereafter (see Malik 2011). Additionally, Maqāșid al-Sharī a h provides valuable intellectual foundation for the subsequent development of an Islamic governance theory. One of the principal objectives of the shari 'ah is the prevention of harm or mafsadah..$^{5}$ There is an abundance of textual proofs to conclude that the removal of corruption (dar' al-mafāsid) and the acquisition of good (jalb al-mașālih) are "the comprehensive objective of the shari 'ah" and the "fundamental universal rule of the Sharì' $a h^{\prime}$ " (Ibn 'Āshūr 2006, 88-90). Muslim jurists believe that any measure that prevents a mafsadah is in line with the objectives of the shari 'ah even if the latter does not provide any indication as to its validity or if provided, that it should not turn a prohibited act into a permissible one and vice versa (Al-Ghazālī 1993, 1:139-140).

However, the harm (mafsadah) due to the dynamic interaction of human life presents itself in a variety of forms. It varies in degrees due to different contexts and societies, and can hardly be enumerated, not even through revelation, considering the dynamism of the development of the human mind and its needs. Hence, the prevention of a certain public harm (mafsadah) to public interest in a certain context requires diversity of approaches and policies. In dealing with the issue of governance, maquassid determines the radius of policies governing the society by accumulating general benefits and avoiding harm to the whole community to enhance public interest (mașlah̆ah 'ämmah). 
Furthermore, this dynamic understanding of the maqāssid offers a better conceptualisation in the field of governance in our contemporary reality. Maqāșid in this sense refers to goals of Islam as a way of life rather than with reference to the legal positivistic goals of fiqh. Meanwhile, maqāssid as objectives of Islam also refer to individual as well as societal considerations beyond the narrow definitional boundaries of fiqhi legal framework. This will enable issues like poverty, inequality, underdevelopment and corruption to be tackled through certain significant governance policies (Siddiqi 2004). In this way, Maqāssid al-Sharī'ah as a holistic theme of Islamic governance must prevail and become the sine qua non in every aspect of the governance process.

The new interpretation of the maqāșid, according to the inclusive definition by Ibn al-Qayyim (1973, 10-19), is thus indispensable in making Islamic governance possible. Limited maqāșid as prescribed through the classical fiqhī orientation is insufficient; therefore, from the legal aspect there is a need for an infinite list based on policy dimension. With this understanding prevailing in the governance process, all policies relating to governance at all levels must aim to attain human well-being as reflected by the revisited notion of Maqāsid al-Sharī ah. This kind of policy-making method is equal to what Ibn al-Qayyim coined, which is al-siyāsah al-shar' iyyah (sharī'ah centric policy-making).

With this new approach to governance issues, Muslims should shift away from the conventional discussions on certain classical institutions that once existed in Muslim history with the goal to re-enact them in contemporary life. The romanticisation of the jurists $(f u q a h \bar{a}$ ') and Islamists to re-establish the utopian "Caliphate Islamic State" should be put to an end before it drags Muslims further downhill to some level of terrorism akin to what had happened to al-Qaeda and ISIS. Instead, Muslims should realise that their political mission in the contemporary life should be dictated with the now and here within the parameters of Maqāșid al-Sharī 'ah. In such a situation, the "good governance" model is an attractive benchmark to be considered by all Muslim nations.

\section{Maqāṣidic Governance: Examples from Islamic Experience}

The term "good governance" implies:

General conduct of which power is exercised by governments and authorities at national, regional and local levels, and the way in which they fulfil their duties of care and accountability in managing and dealing with the economic, social, ecological and cultural resources and institutions for which they are responsible. (Van Dok 1999, 10) 
Governance in this sense is "management of government in a manner that is essentially free of abuse and corruption, and with due regard for the rule of law" and characterised by participation, transparency, accountability, efficiency, effectiveness, equity, etc. This definition encompasses the role of public authorities in establishing the milieu in which other elements of governance function and determine the distribution of benefits (OECD 1995, 14).

This concept is believed by many to be the modern way of ensuring development, harmony and peace amongst the world's population as it combines ideas about political authority, the management of economic and social resources, and the capacity of governments to formulate sound policies and then perform their functions effectively, efficiently and equitably (see Blunt 1995, 1-9), which implies a set of rules (system) governing the actions of individuals and organisations (society) and the negotiation of differences between them that could only be crystallised through proper institutions (Van Dok 1999, 14).

The maquasid exemplifies the conclusion and reflects the fruit of governance that will eventually lead to the attainment of human well-being and should be a major flagship in the policy-making process for development. It should aim to guarantee individual liberty, freedom of choice, rule of law, accountability, transparency, efficiency, sustainability and other governance goals in order to achieve development. Moreover, it establishes its own distinct institutions according to the reality in order to fulfil the highest objectives of sharì $a h$ exemplified by human well-being, development and justice in society.

This whole process of governance, which removes the obstacles to the nourishment of a truthful human life in which all members of the society are able to develop their human capacity in order to obtain personal and social well-being, is but another version of jihāa fì sabill Allāh (strive in the way of Allah). This expanded version of Sabil Allah, as Taleqani pointed out, should be expanded beyond its conventional narrow understanding of merely war to protect people from enemy's transgression to the struggle for the sake of humanity, freedom and the very path of the well-being and betterment of human society (Taleqani 1986, 54-56).

\section{Accountability}

Accountability of the ruler is often used synonymously with concepts such as answerability, enforcement, responsibility, blameworthiness, liability and other terms associated with the expectation of account-giving. The concept of accountability is a condicio, crux of the ideals and the hallmark of good governance. The concept originated from the ethics discourse which has several meanings, but 
its application and expansion has distanced it from its original meaning. In the modern usage, the term "accountability" is synonymous with "responsibility" and "answerability". Upon electing the executive into office with the mandate to rule, tax, spend, legislate and enforce policies and laws; the citizens demand of them accountability. It is thus a double-edged sword which keeps in check the political executive from abusing their power and ensures the effectiveness and efficiency of government operations.

Accordingly, accountability functions as "the mechanism to control power, domesticating it and preventing its abuse under certain procedure by the governed upon the government which governs them" (Malik and Mohd. Nordin 2015). The literature outlines eight types of accountability, namely: political accountability, administrative or bureaucratic accountability, judicial accountability, market accountability, managerial accountability, constituency accountability and professional accountability. Our focus is on political accountability, considering its relevance to our current political situation.

Political accountability has been crucial in defining the rights of the citizen towards preventing injustice and tyranny by those in power. Its realisation enshrines the very idea of good governance. It combines two major elements: enforcement and answerability. These two elements are often described as "hard" and "soft" accountability respectively.

Similarly, enforcement ensures free and fair elections which are institutional prerequisites for democracy. The "freeness" is manifested in the freedom of speech, freedom of association and freedom to participate for every citizen; voter and party. Free elections alone are not sufficient to guarantee the effective role of the accountability process. Elections must also be fair, whereby the rules and procedures are equally fair and protected from fraud and manipulation by those in power. For example, elections should be held at regular intervals so that those currently in office cannot delay them indefinitely according to their whim and fancy to suit their political benefit. Likewise, election as an agent of accountability empowers the voters to assess the policies and performances of their political leaders. Elected political leaders acquire their legitimacy through the voters' voice. The result of elections might be understood simply as a declaration of who most deserves the honour of political authority.

On the other account, answerability can be considered as the core function of accountability. Enforcement, which is the foundation of parliamentary democracies, aims partly to make all parties involved to be answerable of their actions and deliverables before the people. To safeguard the answerability process, 
there must be "openness" and "transparency" in the governance process. These can only be achieved when two other major elements in an authentic ambience of accountability are present: free mass media and legislative scrutiny of the executive.

Freedom of the press is crucial in any democratic country. The media closely monitor the performance of the judicial, legislative and executive bodies. Thus, any abuse of office, corruption, malfunction of the system and its apparatus is reported by the media to inform the public. An informed public would utilise its voting power to punish or reward politicians for their handling (or mishandling) of the nation's affairs. A free press also creates an open space for the public and citizen groups to communicate with each other. Such communication undoubtedly plays a major role in a healthy democratic practice. It helps to raise political consciousness, enhance the free expression of ideas, stimulate proposals for reform, expose flawed thinking, reveal problems before they reach crisis point, mitigate errors and articulate multiple facets of pressing national issues.

However, freedom of the media alone is inadequate without a proper mechanism to make the members of the executive answerable to the public. Answerability requires a legislative institution, which has the power to force the executive to explain its acts of omissions or commissions. This requires the legislative to be constituted on the basis of three principles. First, the recognition of the legitimate right and role of the opposition in all legislative matters. Second, the unrestricted parliamentary scrutiny of all policy matters, its formation, evolution and implementation. Third, the supportive role of parliamentary committees and government agencies. The active role of what Cortina categorised as "special agents" or "institutions" in her framework such as the Anti-Corruption Agency (ACA), Ombudsman or the Public Complaints Bureau in certain countries, Auditor General Office (AG), Public Accounts Committee, and other institutions must be allowed to undertake their task without any interference from the executive. Any regulation, act or law that restricts the freedom of these agencies is undemocratic and would jeopardise the accountability process.

In summary, accountability is the hallmark of good governance which embraces the enforcement of free and fair elections and answerability of the executive to the public in a political space of openness and transparency. The malfunction of any of these critical operating systems will retard national development and progress. However, the accountability system can only be highly efficient with the existence and support of other related concepts of governance such as rule of law, people participation and a higher degree of civil liberty. If political accountability is unheeded, neglected or dysfunctional, citizens may inevitably resort to civil 
disobedience, street protests, rebellions or violent revolutions. After all, the people affected are the best interpreters of their needs (Cortina 2007, 14).

Similarly, it is widely accepted that the practice of good governance leads to higher investment and growth, hence development. And political accountability has been highly regarded as one of the sine qua non elements in the governance equation. Transparency in party financing as well as asset disclosure are amongst the crucial characteristics of political accountability in many developed nations. A myriad of researches and reports have shown that the lack of openness in money and politics has often contributed to the corruption of political finance. Thus, policymakers aspiring for sustainable national development must seriously address the transparency of money in politics.

\section{Transparency}

Disclosure is one of the many ways by which nations have tried to control the flow of money into politics. From the perspective of the electorate and civil society, disclosure enables them to see from where the political money originates, how it flows and how it may influence legislative behaviour. To politicians or political parties, disclosure means giving up some modicum of privacy to gain credibility through the practice of accountability. The need for more disclosure laws means that parties simply need to be more open about their honest money and allow more transparency. In a democracy, disclosure reports are to politics, what financial statements are to businesses. Both are "accounting systems"; one for the accuracy of profits, the other for the level of accountability of elected leaders.

Increasing emphasis on transparency in politics engenders a lot of benefit to the people and nation. It will first and foremost increase the legitimacy and credibility of the political governance. Illegal money can too easily find its way into the governance equation and cast aspersions. A "pornography king" was found to have contributed a large sum of money to the Labour Party in the UK and more than just eyebrows were raised. In Latin America, many still remember the financial scandal between the president of Colombia and the drug lords. Without disclosure, money can come from anywhere in the world, and in incredible amounts too. And since money often determines the victor in a political contest, the transparency of fiscal origins and its use are fundamental!

No disclosure means no enforcement is ever possible. Without disclosure reporting requirements for contributions, there would be no way to enforce campaign contribution limits. Without disclosure of spending, there could be no way of enforcing spending limits. Without disclosure of a donor's identity and 
citizenship, there is no way to enforce bans on foreign contributions. Countries that have meagre enforcement of political finance will most likely have weak or non-existent disclosure laws.

Transparency builds confidence in the democratic process. A government that is transparent, open and accountable enhances its credibility and enjoys the trust and confidence of its citizens. The rakyat (citizens) feel comfortable and reassured with their government and political leaders who are responsible and transparent about public and political finances. In contrast, the lack of transparency makes people lose confidence in both the government and the system.

\section{Islamic Principles for Accountability and Transparency}

Accountability and transparency in Islam are derived from the concept of amanah. Amänah as a political concept suggests that God has given the trust to human beings to deliver and promote His guidance through justice and fairness in their lives. Everyone becomes a recipient of such a trust and consequently has to stand in awe-filled reverence before his people towards whom and for whose sake he will be called upon to exercise his duty. This concept is enshrined in the Qur'an: "Let there arise out of you a band of people inviting to all that is good, enjoining what is right, and forbidding what is wrong: They are the ones to attain felicity" (Qur'an $3: 104)$. This verse and the similar illustrate that Islam promotes active citizenship through participation in governance. The spirit of al-amr bi al-ma' rüf wa nahy 'an al-munkar (enjoinment of good and forbidding of evil) must be expanded from the exclusivity of spiritual-ritual dimension towards a broader and holistic horizon of moral, ethical, social and political responsibilities. In harmony with the Qur'anic spirit, the Prophet was reported as saying: "Whoever amongst you sees anything objectionable, let him change it with his hand, if he is not able, then with his tongue, and if he is not even able to do so, then with his heart, and the latter is the weakest form of faith" (narrated by Muslim).

Similarly, there are other analogous records which denote the Prophet's position on the political life of the believers, amongst others his praise and recognition of anyone who stood against tyranny with the words of justice: "The master of the martyrs is Hamza, and whoever is killed speaking truth in the court of a tyrant ruler" (narrated by al-Hakim).

Equally, on another occasion he justified an act of accountability performed by an individual by associating it with jihad: "The best jihad is the word of truth to an unjust ruler" (narrated by al-Tirmidhī, Abū Dāwūd and Ibn Mājah). 
These evidences from authentic texts demonstrate that "accountability" is pivotal in articulating the purity of the spirit of amānah in political life. The high sense of accountability empowers individuals, hence crystallising the true meaning of equality and allowing individuals to act as a benchmark for the community of believers. These inter-dependent and inter-relating concepts reveal a clear picture of how amānah works within a tawhīdic worldview-based society. Furthermore, in preserving and instilling the concept of accountability, the Prophet allowed himself to be accountable and criticised by his companions on many occasions. The Prophet was criticised by the companions on his decision regarding the positioning of the army during the Battle of Badr. He was also urged to accept the companions' proposal to fight the Makkan army outside Madinah when the Makkan troops were approaching Madinah during the Battle of Uhud.

The practice of accountability and transparency in early Islamic political life could also be found during the period of the first Caliph, Abu Bakr. He stressed the importance of accountability and the nature of individuals with authority in the community in his very first speech to the Muslim community after being elected as the Caliph by saying: "Cooperate with me when I am right, but correct me when I commit error; obey me so long as I follow the commandments of Allah and His Prophet; but turn away from me when I deviate" (narrated by al-Hindī).

In fact, other companions often held him to account for his decisions and state administration. Furthermore, this was also the position of 'Umar when he was elected as the successor of Abu Bakr. In his very first speech after being appointed as the second Caliph, he stressed the need for accountability in his administration, and the rights of every empowered citizen.

'Umar's policy on accountability and transparency did not end with the primitive style of verbal complaints and condemnation from the public. He established a specific office to deal with the public administrators' accountability. The office was designed for the investigation of complaints that reached the Caliph against the officers of the State.

Another example of accountability and transparency practiced during the period of the rightly-guided Caliphs can be found in the famous letter written by the fourth Caliph, 'Alī ibn Abī Țālib to his governor of Egypt, Mālik al-Ashtar. In his advice to the governor, he asserted that:

Out of your hours of work, fix a time for the complainants and for those who want to approach you with their grievances. During this time, you should do no other work but hear them and pay attention to their 
complaints and grievances. For this purpose you must arrange public audience for them; during this audience, for the sake of Allah, treat them with kindness, courtesy and respect. Do not let your army and police be in the audience hall at such times so that those who have grievances against your regime may speak to you freely, unreservedly and without fear. (Al-Musawi 2007, 2:459)

\section{Conclusion}

The whole idea of Maqāsid al-Sharī ah implies a comprehensive implementation of justice in the community through the preservation and promotion of human well-being, which is the ultimate aim of the governance process. While the idea is consistent with Cortina's Model of Development Ethics framework to a certain degree, it goes beyond the notion of attaining the internal goods within ethical principles through the cultivation of values and virtues by different agents of institutions based on specific philosophical foundations. Rather, Maqāșid alSharì $a h$, as an integral part of epistemological sources in Islam, is becoming a foundation to define human well-being. Thus, the articulation of Islamic ethos that might be useful for governance will be taken under the shade of this maqāsidicbased human well-being consideration.

The activation of Maqāsid al-Sharī'ah within such an understanding is inspired among others by the spirit of verse in the Qur'an (2:177):

It is not righteousness that you turn your faces towards East or West; but it is righteousness to believe in Allah and the Last Day and the Angels and the Book and the Messengers; to spend of your substance out of love for Him, for your kin, for orphans, for the needy, for the wayfarer, for those who ask; and for the ransom of slaves; to be steadfast in prayers and practice regular charity; to fulfil the contracts which you made; and to be firm and patient in pain (or suffering) and adversity and throughout all periods of panic. Such are the people of truth, the God-fearing.

If Maqāsid al-Sharī'ah is to be perceived as the aim through the articulation of falah, hence it is no longer merely a mechanistic element to the governance process, instead it is a means and goal by itself. Therefore, good governance from the Islamic view is a process that consists of the maqassidic elements to fulfil the maqāsidic end. According to this understanding, the governance process is not just a consequence of independent deontological activity just for the discharge of responsibilities for the sake of delivering the vicegerency tasks. In fact, it is to be viewed from a virtue-based consequentialistic paradigm, as it is a process to attain 
a holistic end for the benefit of individual through its tawhìdic paradigm, which goes beyond the instrumental value meaning.

This paradigm imposes multi dimensions of benefits, which encompass both individuals and community benefits, in this world and the hereafter. The whole process of governance within such a framework is not only a mere process as mentioned, and not only for the pursuit of happiness of individuals, but also for the community, although not at the expense of other individuals. This goal is similar to that espoused by Confucius in his "Spring and Autumn Period" as, "good government is attained when those who are near are made happy, and those who are far away are attracted" (Clements 2000, 44). It summarises the comprehensive meaning of solidarity-inspired mutual kindness and multiple-happiness for individuals (Cortina 2007, 16). The field of governance is rather a new and fertile field of $i j t i h \bar{a} d$. Applying or imposing certain classical or archaic structures or concepts on the new reality will not bring about a realistic result due to the incompatibility of the two. Instead, a fresh and innovative exploration should be initiated to understand the spirit and ethos of Maqāssid al-Sharī ah and incorporate it into the new reality. Similar to the jurists (classical and contemporaries) who produced and are still producing their ijtihād in formulating the ideal model of "Islamic Governance", all exploration beyond the parameter of fiqh is also considered as a continuous ijtihäd process to bring people close to the ideals. As human life is constantly changing, no definite model could be promulgated as the final result in defining the Islamic model of governance. It is an on-going journey and the end is not yet in sight. Like the saying, "it is better to travel hopefully than to arrive", or the ancient Taoist saying, "the journey is the reward".

\section{Notes}

1. Davenport says: "The Qur'an is the general code of the Muslim world, a social civil, commercial, military, judiciary, criminal, penal and yet religious code. By it everything is regulated - from the ceremonies of religion to those of daily life, from the salvation of the soul to the health of the body, from the rights of general community to those of each individual, from the interest of man to those of society, from morality to crime, from punishment here to that of the life to come" (Davenport 2009 [1882], 48-49).

2. Gibb explains: "For Muslims its proof-texts were to be found in the Koran and Prophetic Tradition; and on this assumption the jurists and theologians of the second century elaborated a structure of Law that is, from the point of view of logical perfection, one of the most brilliant essays of human reasoning" (Gibb 1958, 73-74).

3. Al-Ghazali $(1993,258)$ suggests that: "In its essential meaning, it (mașlahah) is an expression for seeking something useful (manfa' $a h$ ) or removing something harmful (madarrah). But this is not what we mean, because seeking utility and removing 
harm are the purposes (maqāsid) at which the creation (khalq) aims and the goodness (salah) of creation consists in realising their goals (maqāssid). What we mean by mașlahah is the preservation of the maqāșid (objective) of the Sharī'ah law, which consists of five things: preservation of religion, of life, of reason, of descendants and of property. What assures the preservation of these five principles (ușūl) is mașlahah and whatever fails to preserve them is mafsadah and its removal is mașlahah".

4. Al-Juwayni who preceded al-Ghazali also points out that the mașlahah (benefit) (which he classified into three categories) are to be "protected" (Awdah 2006).

5. The word mafsadah, derived from the root word fasada or fasad, has been mentioned almost 50 times in the Qur'an and has a wide range of meanings, amongst others: "a state of disorder, or disturbance, or of destruction, annihilation, waste, or ruin" (Lane 1978, 1:2396). It also connotes mischief, corruption, exploitation, wrong and all forms of injustice, mismanagement, anarchy and chaos. Fasad is the opposite of islah, derived from the root word SaLaHa, which literally means "good, incorrupt, sound, right, or a proper state, or in a state of order" (Lane 1978, 2:216). Islah refers to a state of equilibrium where things are in a proper order and balance. Muslim jurists have also used the words sharr (evil) and İarar (harm) as synonymous with mafsadah.

\section{References}

'Abd al-Salam, 'Izz al-Dīn. n.d. Qawà'id al-Ahkām. Beirut: Dār al-Kutub al- 'Ilmiyyah. 'Abduh, Muhammad. 1966. The theology of unity (translated by I. Musaad and K. Cragg). London: Allen and Unwin

Akhtar, Sayyid Wahid. 1995. The Islamic concept of knowledge. Al-Tawhīd: A Quarterly Journal of Islamic Thought 12(3).

Al-Alwani, Taha J. 1991. Toward a proper reading of the Sunnah. Virginia: International Institute of Islamic Thought.

Al-Ghazālī, Abū Hāāmid Muḥammad. 1993. Al-Mustaşā̄ fí 'Ilm al-Uṣul. Beirut: Dār al-Kutub al-'Ilmiyyah.

Al-Musawi, Muhammad ibn Husayn. 2007. Nahj al-Balaaghah: Selections from sermons, letters and sayings of Ali bin Abi Talib (5th ed.) (translated by Sayyid Ali Reza). Qum: Ansariyan Publications.

Al- 'Ubaydī, Hammādī. 1992. Al-Shātibī wa Maqāṣid al-Sharī. Tripoli: Manshūrāt Kulliyyah al-Da'wah al-Islāmiyyah.

Al-Qaraḍāwī, Yūsuf. 1993. Malāmị̣ al-Mujtama' al-Muslim alladhī Nanshuduhu. Cairo: Maktabah al-Wahbah.

Al-Qaraḍāwī, Yūsuf. 2004. Kayfa nata'amal ma'a al-Turāth wa al-Tamadhhub wa alIkhtiläf. Cairo: Maktabah al-Wahbah.

Al-Shāṭib̄̄, Ibrāhīm ibn Mūsā. 1996. Al-Muwāfaqāt. Beirut: Dār al-Ma rifah.

Al-Ṭufì, Najm al-Dīn. 1989. Al-Ta'yin fi Sharh al-Arba'inn. Beirut: Mu'assasah al-Risālah. 'Awdah, Jāsir. 2006. Fiqh al-Maqāṣidĩ: Inatah al-Aḥka'm al-Shar'iyyah bi Maqāșidihā [Fiqh al-Maqāṣidi: Formulation of Islamic legal rulings through Islamic higher objectives of shari'ah]. Virginia: International Institute of Islamic Thought. 
Blunt, P. 1995. Cultural relativism, 'good governance' and sustainable human development. Public Administration and Development 15(1): 1-9. https://doi.org/10.1002/ pad.4230150102

Casanova, J. 1994. Public religions in the modern world. Chicago: University of Chicago Press.

Chapra, M.U. 1992. Islam and the economic challenge. Leicester: Islamic Foundation. 2008a. Muslim civilization: The cause of decline and the need for reform. Leicester: The Islamic Foundation. . 2008b. The Islamic vision of development in the light of Maqāsid al-Sharī'ah. London and Washington: International Institute of Islamic Thought.

Choudhury, M. 1992. The foundations of Islamic political economy. London and New York: Macmillan.

1993. The unicity precept and the socio-economic order. Lanham: University Press of America.

1994. A theory of ethico-economics. Hull: Barmarick Publications.

1999. The structure of Islamic economics: A comparative perspective on markets, ethics and economics. Consumption, Markets and Culture 3(1): 61-97. https://doi. org/10.1080/10253866.1999.9670330

Clements, J. 2000. The little book of Chinese proverbs. Bath: Parragon Book.

Collins English Dictionary. 1998. Glasgow: HarperCollins Publishers.

Cortina, A. 2007. Development ethics: A road to peace. Paper presented at a public lecture in honoring Prof. Denis Goulet, University of Notre Dame.

Davenport, J. 2009 [1882]. An apology for Mohammad and the Koran. London: J. Day and Sons.

Enayat, H. 1982. Modern Islamic political thought. London: Palgrave Macmillan.

Falk, R. 2001. Religion and humane global governance. New York: Palgrave.

Fowler, W. and Fowler, F.G. (ed.). 1995. The concise Oxford dictionary of current English. Oxford: Clarendon Press.

Ghaus-Pasha, A. 2005. Role of civil society in governance. Paper presented at the Sixth Global Forum on Reinventing Government, Seoul, South Korea.

Gibb, H.A.R. 1958. Mohammedanism. Cambridge: Mentor Edition.

Gillingham, R. 2005. Praxis and the content of theology in Gustavo Gutiérrez's theological methodology: A comparative critique. Quodlibet Journal April-June 7(2). http:// www.quodlibet.net/articles/gillingham-gutierrez.shtml

Gutiérrez, G. 1988. A theology of liberation: History, politics and salvation. New York: Orbis Books.

Harrigan, J. and El-Said, H. 2009. Economic liberalisation, social capital and Islamic welfare provision. Basingstoke: Palgrave Macmillan. https://doi. org/10.1057/9781137001580

Ibn al-Qayyim, Muhammad ibn Abū Bakr. 1973. I' läm al-Muwaqi' in 'an Rabb al-'Alamin. Beirut: Mațba' ah Bayrūt.

Ibn 'Āshūr, Muhammad al-Ṭāhir. 2006. Ibn 'Ashhūr Treatise on Maqūṣid al-Sharī'ah (translated by Tahir el-Mesawi). Virginia: International Institute of Islamic Thought.

Ibn Khaldūn, 'Abd al-Raḥmān. 2005 [1967]. The Muqaddimah: An introduction to history (translated by Franz Rosenthal). New Jersey: Princeton University Press. 
Jansen, J.J.G. 1974. The interpretation of the Qur'an in modern Egypt. Leiden: E.J. Brill. Lane, E.W. 1978. Arabic-English lexicon. London: Longman.

Malik, M. 2011. Constructing the architectonics and formulating the articulation of Islamic governance: A discursive attempt in Islamic epistemology. $\mathrm{PhD}$ dissertation, Durham University.

2015. Good governance, civil society and Islam. Kuala Lumpur: IIUM Press.

Malik, M. and Mohd. Nordin, M. 2015. Political accountability: An Islamic viewpoint. http://mpf.org.my/wp/?p=1452.

Marshall, K. 2005. Faith and development: Rethinking development debates (World Bank paper, June). New York: World Bank.

OECD (Organisation for Economic Co-operation and Development). 1995. The DAC guidelines: Poverty reduction. Paris: OECD Publications Service.

Phongphit, S. 1988. Religion in a changing society: Buddhism, reform and the role of monks in community development in Thailand. Hong Kong: Arena Press.

Rahman, F. 1979. Islam. Chicago: University of Chicago Press.

Ramadan, T. 2006. Ijtihad and maslaha: The foundation of governance. In Islamic democratic discourse, ed. M.A. Muqtedar Khan, 3-20. Oxford: Lexington Books.

Rowland, C. 1999. The Cambridge companion to liberation theology. Cambridge: Cambridge University Press.

Siddiqi, M.N. 2004. What went wrong? Keynote address at the Roundtable on Islamic Economics: Current State of Knowledge and Development of Discipline, Jeddah, Saudi Arabia on 26-27 May 2004 under joint auspices of the Islamic Research and Training Institute, Jeddah; and the Arab Planning Institute, Kuwait.

Taleqani, Ayatullah Mahmud. 1986. Jihad and shahadat. In Jihad and shahadat: Struggle and martyrdom in Islam, eds. M. Abedi and G. Legenhausen, 47-80. North Haledon and New Jersey: Islamic Publications International.

Van Dok, G. 1999. Good governance: Paper tiger of source of hope, critical reflections on the success of foreign policy concepts (Discussion Paper 6). Lucerne: Caritas Press. 